\title{
Effects of Macronutrients in the Physiological Quality of Soybean Seeds
}

\author{
Geliandro Anhaia Rigo ${ }^{1}$, Luis Osmar Braga Schuch ${ }^{1}$, Willian Silva Barros ${ }^{1}$, Rodrigo Lamaison de Vargas ${ }^{1}$, \\ Vinícius Jardel Szareski ${ }^{1}$, Ivan Ricardo Carvalho ${ }^{1}$, João Roberto Pimentel ${ }^{1}$, Cristian Troyjack ${ }^{1}$, \\ Lucian Alex dos Santos ${ }^{1}$, Francine Lautenchleger ${ }^{3}$, Tiago Corazza da Rosa ${ }^{1}$, \\ Velci Queiróz de Souza ${ }^{2}$, Tiago Zanatta Aumonde ${ }^{1} \&$ Tiago Pedó$^{1}$ \\ ${ }^{1}$ Federal Universityof Pelotas, Capão do Leão, RS, Brazil \\ ${ }^{2}$ Federal University of Pampa, Dom Pedrito, RS, Brazil \\ ${ }^{3}$ State University of Londrina, Londrina, PR, Brazil \\ Correspondence: Ivan Ricardo Carvalho, Universidade Federal de Pelotas, Campus Capão do Leão, CEP \\ 96050-500, Capão do Leão, RS, Brazil. Tel: 55-9640-8757. E-mail: carvalho.irc@gmail.com
}

Received: October 17, 2017

doi:10.5539/jas.v10n5p312
Accepted: March 11, $2018 \quad$ Online Published: April 15, 2018

URL: https://doi.org/10.5539/jas.v10n5p312

\begin{abstract}
The aim of this work was to correlate macronutrient content of soybean seeds to physiological quality of different cultivars. The work was developed in the Federal University of Pelotas, in the facilities of the Seed Science and Technology Graduate Program. The experimental design was randomized blocks in arranged in four replicates. The following soybean cultivars were used: BMX Apolo RR (12 lots), BMX Ativa RR (13 lots), BMX Energia RR (26 lots), BMX Força RR (24 lots), BMX Impacto RR (35 lots), BMX Magna RR (16 lots), BMX Turbo RR (44 lots), BMX Potência RR (82 lots) and NA 5909 RR (28 lots), with seeds produced in northwest Rio Grande do Sul. The determination of nutritional contents found in plant tissues of soybean seeds, were measured: Nitrogen (N), Phosphorus (P), Potassium (K), Magnesium (Mg), Calcium (Ca), Sulfur (S). The macronutrient contents of the seeds vary according to genetic characteristics of the cultivars, with higher oscillations of nitrogen, phosphorus, magnesium and sulfur contents present in soybean seeds. Potassium and calcium are defined as the most stable nutrients for the cultivars and seed lots analyzed. High concentrations of nitrogen, phosphorus and calcium are determinants for the physiological quality of soybean seeds.
\end{abstract}

Keywords: nutritional composition, minerals, interrelationships

\section{Introduction}

The soybean crop stands out with $49 \%$ of the Brazilian agricultural area. This increase is mainly due to factors related to crop management and several utilization purposes (Ferrari et al., 2014). In view of this, the soybean production chain is well structured in most producing countries, where new technologies and modernization of agricultural techniques allowed to better exploit the yield potential, thus increasing soybean productivity, besides the stability of market and its socioeconomic importance (Carvalho et al., 2017).

The use of seeds with high physiological quality plays fundamental role for a crop to achieve high yields, since seedsof high quality have faster metabolic processes, providing auniform emission of the primary root during germination and higher growth rate, originating seedlings with higher initial stature, growth and grain yield (Schuch et al., 2009; Peske et al., 2012; Szareski et al., 2016). The physiological quality of the seeds may be influenced, both positively and negatively, by many factors, where the nutrients play determinant role (Follmann et al., 2014). Soybean seeds from different cultivars and lots vary in chemical composition due to cultivation in different environments, reflecting on their physiological quality (Delarmino-Ferraresi et al., 2014; Szareski et al., 2015).

Nitrogen, phosphorus, calcium and magnesium stand out among the macronutrients with positive responses in seed quality, however not only the element itself, but also the content supplied to the plants may influence on seed quality (Marcos Filho, 2015). Kurihara et al. (2013), evaluating nutrient accumulation in soybean seeds, verified concentrations of $\mathrm{N}\left(235 \mathrm{~g} \mathrm{~kg}^{-1}\right), \mathrm{P}\left(24 \mathrm{~g} \mathrm{~kg}^{-1}\right), \mathrm{K}\left(54.4 \mathrm{~g} \mathrm{~kg}^{-1}\right) \mathrm{Ca}\left(9.1 \mathrm{~g} \mathrm{~kg}^{-1}\right) \mathrm{Mg}\left(11.4 \mathrm{~g} \mathrm{~kg}^{-1}\right)$. López-andreu et al. (1985) evidenced minimal differences between cultivars sown at the same growing 
environment, being $\mathrm{K}, \mathrm{P}, \mathrm{Mg}$ and $\mathrm{Ca}$, the most abundant nutrients, with $19.6 \mathrm{~g} \mathrm{~kg}^{-1}, 4.54 \mathrm{~g} \mathrm{~kg}^{-1}, 2.59 \mathrm{~g} \mathrm{~kg}^{-1}$ and $3.13 \mathrm{~g} \mathrm{~kg}^{-1}$, respectively.

In the early stages of development, during seedling emergence and establishment, the seeds macronutrient content allows to determine if they are in an enough range for suitable physiological processes. In this context, the aim of this work was to correlate macronutrient content of soybean seeds to physiological quality of different cultivars.

\section{Materials and Methods}

The work was developed in the Federal University of Pelotas, in the facilities of the Seed Science and Technology Graduate Program. The experimental design was randomized blocks in arranged in four replicates. The following soybean cultivars were used: BMX Apolo RR (12 lots), BMX Ativa RR (13 lots), BMX Energia RR (26 lots), BMX Força RR (24 lots), BMX Impacto RR (35 lots), BMX Magna RR (16 lots), BMX Turbo RR (44 lots), BMX Potência RR (82 lots) and NA 5909 RR (28 lots), with seeds produced in northwest Rio Grande do Sul.

The determination of nutritional contents found in plant tissues of soybean seeds was carried out at the Laboratory of Chemical Analysis of the Brazilian Institute of Analyzes (IBRA) located in Sumaré, SP. Where Nitrogen (N), Phosphorus (P), Potassium (K), Magnesium (Mg), Calcium (Ca), Sulfur (S) were measured. The nutrient extraction was carried out according to the methodology proposed by Malavolta (2006). For N extraction, the sulfuric digestion method was used, where $\mathrm{H}_{2} \mathrm{SO}_{4}$ in the presence of catalysts $\left(\mathrm{CuSO}_{4} \cdot 5 \mathrm{H}_{2} \mathrm{O}\right.$, $\mathrm{Na}_{2} \mathrm{SeO}_{3}$ ) and salts used to increase the acid ebullition point, as $\mathrm{Na}_{2} \mathrm{SO}_{4}$, where organic matter was oxidized by transforming the nitrogen into ammonium sulfate $\left(\mathrm{NH}_{4}\right)_{2} \mathrm{SO}_{4}$.

For $\mathrm{P}, \mathrm{K}, \mathrm{Ca}, \mathrm{Mg}$ and $\mathrm{S}$ extraction, it was used the method of decomposition by nitric-perchloric digestion. Dry matter $(0.50 \mathrm{~g})$ was treated with $9.0 \mathrm{~mL}$ of nitric-perchloric mixture in a proportion of $3.5: 1(\mathrm{v} / \mathrm{v})$, and pre-digestion was performed at room temperature for 12 hours. The samples were digested in a heating plate with temperature of $160{ }^{\circ} \mathrm{C}$, where they were kept until their volume reduced to $50 \%$ of the total. Then, the temperature was raised to $200^{\circ} \mathrm{C}$, remaining until the extract became colorless. After cooling, $2 \mathrm{~mL}$ of ultra-pure water was added, the extract was then transferred to a $50 \mathrm{~mL}$ volumetric flask, completing the volume with ultra-pure water. The reading solution was homogenized and transferred to glass vials to rest during 12 hours for amorphous silica decantation.

Nitrogen was determined by the Semi-micro-Kjeldahl method, based on the transformation of ammoniacal nitrogen $\left(\mathrm{NH}_{4}\right)_{2} \mathrm{SO}_{4}$ to ammonia $\left(\mathrm{NH}_{3}\right)$, which is fixed by boric acid and then titrated with $\mathrm{H}_{2} \mathrm{SO}_{4}$ until further formation of $\left(\mathrm{NH}_{4}\right)_{2} \mathrm{SO}_{4}$ in the presence of acid/base indicators. Phosphorus was determined by the Metavanadate (total phosphorus) Colorimetry. The developed color is measured in a photocolorimeter or spectrophotometer using a color filter complementary to the sample, the percentage of transmission (\% T), absorbance (A) or optical density (O.D.) was measured. The determination of Potassium was obtained by atomic absorption spectrometry, and after the oxidation of the plant material by nitric-perchloric digestion, the potassium is quantified by atomic absorption spectrophotometer with $\mathrm{K}(\mathrm{Lc})$ hollow cathode lamp.

Calcium and magnesium were quantified in atomic absorption spectrophotometer with calcium or magnesium discharge arc lamps, and for the determination of these two elements, the addition of lanthanum or strontium is necessary to prevent interference caused by the presence of phosphates and aluminum. Thus, lanthanum or strontium prevents the formation of thermally stable compounds between magnesium or calcium. Sulfur was determined by the Turbimetry method of barium sulphate, based on the turbidity formed by sulfur precipitation through barium chloride, a spectrophotometer was used to determine the transmittance ( $\mathrm{T}$ ) or absorbance. For all the macronutrients measured in the seeds, the results were expressed in grams per kilo $\left(\mathrm{g} \mathrm{kg}^{-1}\right)$.

The physiological quality of the seeds was based on the germination test (GER), conducted in four sub-samples of 100 seeds per replicate of each treatment, where seeds were arranged in Germitest paper rolls moistened with water equivalent to 2.5 times the mass of the dried paper, remaining in a germinator at $25^{\circ} \mathrm{C}$. The evaluations were carried out eight days after sowing, according to the Rules for Seed Analysis (Brazil, 2009), and the results were expressed as percentage of normal seedlings.

Accelerated aging (AA) was carried out in a gerbox with metallic screen. $40 \mathrm{~mL}$ of distilled water was added to the bottom of the box, and the seeds of each lot were uniformly distributed over the screen in a single layer. Then, the seed boxes were conditioned in a BOD incubator at $41{ }^{\circ} \mathrm{C}$, where they remained for 48 hours. Afterward, they were submitted to germination test (Marcos Filho et al., 1999). 
Viability by the tetrazolium test (PG), carried out with four samples of 50 seeds of each lot, these being pre-conditioned on paper towels moistened at $30{ }^{\circ} \mathrm{C}$ in a humid environment (germinator) for 16 hours. After this period, the seeds were transferred to plastic containers and immersed in $0.075 \%$ tetrazolium salt solution, which were kept for four hours in an oven at $40{ }^{\circ} \mathrm{C}$. After coloration staining, the seeds were washed in running water and evaluated according to the criteria proposed by Costa et al. (2007). The weight of one thousand seeds (WTS) was determined by weighing eight replicates of 100 seeds, followed by the adjusted to weight of one thousand seeds (Brazil, 2009).

The data were submitted to analysis of variance at $5 \%$ of probability, with assumptions verification. The characters that showed significance were submitted to complementary analyzes by Tukey at $5 \%$ of probability. Posteriorly, the characters were submitted to linear correlation analysis.

\section{Results and Discussion}

Significance was verified for all measured characters at $5 \%$ of probability, and it was possible to observe the presence of correlation between macronutrients contents in soybean seeds and physiological quality of different cultivars. There was high positive correlation between nitrogen content and germination for the cultivars BMX Apolo RR, BMX Ativa RR, BMX Impacto RR and BMX Potência RR (Table 1). Accelerated aging positively correlated with nitrogen content in soybean seeds for cultivars, BMX Apolo RR, BMX Impacto RR, BMX Magna RR andBMX Potência RR (Table 1).

Table 1. Pearsons correlation between macronutrient contents and the characters germination (Ger), accelerated aging (AA), viability by tetrazolium test (PG), vigor by tetrazolium test (Vtz) and weight of one thousand seeds (MTS) in different growing cultivars

\begin{tabular}{|c|c|c|c|c|c|c|c|c|c|c|}
\hline \multirow{2}{*}{ Cultivars } & \multicolumn{5}{|c|}{$\mathrm{N}$} & \multicolumn{5}{|c|}{$\mathrm{P}$} \\
\hline & Ger & AA & PG & $\mathrm{VTz}$ & MTS & Ger & AA & PG & VTz & WTS \\
\hline BMX Apolo RR & $0.78 *$ & $0.94 *$ & 0.27 & 0.04 & $0.97 * *$ & $0.99 * *$ & 0.58 & $0.77 *$ & 0.60 & 0.67 \\
\hline BMX Ativa RR & $0.78^{*}$ & 0.31 & $0.70^{*}$ & 0.56 & 0.16 & $0.84 *$ & 0.64 & $0.70^{*}$ & 0.67 & 0.63 \\
\hline BMX Energia RR & -0.18 & -0.12 & 0.40 & 0.23 & -0.24 & 0.47 & 0.48 & 0.42 & 0.40 & -0.39 \\
\hline BMX Força RR & 0.15 & 0.13 & 0.33 & 0.03 & 0.10 & 0.18 & $0.79 *$ & 0.53 & 0.56 & 0.40 \\
\hline BMX Impacto RR & $0.89 * *$ & $0.75 *$ & $0.95 * *$ & $0.93 * *$ & 0.40 & 0.48 & 0.36 & $0.63 *$ & $0.65^{*}$ & 0.22 \\
\hline BMX Magna RR & 0.05 & $0.69 *$ & 0.34 & 0.16 & $0.77 *$ & 0.50 & 0.50 & 0.44 & 0.46 & 0.15 \\
\hline NA 5909 RR & 0.57 & 0.52 & $0.76^{*}$ & $0.75 *$ & 0.58 & $0.70 *$ & 0.07 & 0.21 & 0.41 & 0.26 \\
\hline BMX Potência RR & $0.80 *$ & $0.77 *$ & 0.23 & 0.16 & 0.12 & $0.81 *$ & 0.43 & $0.85^{*}$ & $0.80 *$ & $0.73^{*}$ \\
\hline BMX Turbo RR & 0.45 & 0.41 & 0.39 & 0.46 & $0.64 *$ & $0.94 * *$ & $0.86^{* *}$ & $0.65 *$ & 0.57 & $0.74 *$ \\
\hline \multirow{2}{*}{ Cultivars } & \multicolumn{5}{|c|}{$\mathrm{K}$} & \multicolumn{5}{|c|}{$\mathrm{Ca}$} \\
\hline & Ger & $\mathrm{AA}$ & PG & $\mathrm{VTz}$ & PMS & Ger & AA & PG & $\mathrm{VTz}$ & WTS \\
\hline BMX Apolo RR & 0.55 & 0.50 & 0.60 & 0.52 & -0.54 & $0.85 *$ & $0.74 *$ & $0.70 *$ & 0.41 & $0.82 *$ \\
\hline BMX Ativa RR & $0.83 *$ & 0.78 & 0.67 & 0.34 & 0.30 & $0.75^{*}$ & 0.05 & 0.62 & 0.19 & -0.07 \\
\hline BMX Energia RR & -0.59 & -0.62 & -0.14 & -0.45 & 0.64 & $0.89 *$ & $0.79 *$ & 0.40 & 0.25 & 0.30 \\
\hline BMX Força RR & -0.02 & 0.01 & 0.52 & 0.36 & 0.30 & -0.10 & -0.20 & -0.09 & -0.09 & 0.37 \\
\hline BMX Impacto RR & 0.57 & 0.47 & 0.54 & $0.64 *$ & 0.08 & 0.35 & 0.51 & 0.02 & -0.06 & 0.35 \\
\hline BMX Magna RR & 0.53 & 0.12 & 0.57 & 0.57 & -0.05 & 0.01 & $0.87 * *$ & 0.50 & 0.59 & 0.09 \\
\hline NA 5909 RR & 0.25 & 0.12 & 0.24 & 0.18 & -0.41 & $0.86^{*}$ & $0.76^{*}$ & 0.42 & 0.47 & -0.28 \\
\hline BMX Potência RR & 0.33 & 0.41 & 0.08 & -0.05 & -0.02 & 0.40 & $0.72 *$ & $0.65 *$ & 0.44 & 0.31 \\
\hline BMX Turbo RR & 0.45 & 0.33 & 0.31 & 0.49 & -0.51 & 0.14 & -0.20 & 0.24 & 0.16 & 0.07 \\
\hline \multirow{2}{*}{ Cultivars } & \multicolumn{5}{|c|}{$\mathrm{Mg}$} & \multicolumn{5}{|c|}{$\mathrm{S}$} \\
\hline & Ger & $\mathrm{AA}$ & $\mathrm{PG}$ & $\mathrm{VTz}$ & PMS & Ger & $\mathrm{AA}$ & PG & VTz & WTS \\
\hline BMX Apolo RR & 0.51 & 0.22 & 0.59 & 0.60 & 0.10 & 0.19 & -0.13 & 0.58 & 0.51 & -0.25 \\
\hline BMX Ativa RR & -0.20 & 0.02 & -0.28 & -0.46 & 0.16 & 0.15 & -0.51 & -0.03 & 0.19 & -0.20 \\
\hline BMX Energia RR & -0.25 & -0.29 & -0.11 & -0.26 & 0.28 & -0.03 & -0.07 & -0.15 & -0.43 & 0.31 \\
\hline BMX Força RR & 0.14 & 0.12 & 0.53 & 0.36 & 0.39 & -0.03 & -0.04 & 0.27 & 0.13 & 0.35 \\
\hline BMX Impacto RR & 0.39 & 0.43 & 0.49 & 0.60 & 0.40 & $0.80 * *$ & $0.82 * *$ & $0.65 *$ & $0.66^{*}$ & 0.08 \\
\hline BMX Magna RR & 0.58 & 0.55 & 0.55 & 0.67 & 0.02 & -0.48 & 0.19 & 0.16 & 0.16 & -0.03 \\
\hline NA 5909 RR & -0.53 & 0.04 & -0.19 & -0.34 & 0.43 & 0.14 & 0.07 & -0.15 & -0.13 & 0.26 \\
\hline BMX Potência RR & 0.11 & 0.28 & 0.47 & 0.17 & 0.47 & 0.52 & 0.46 & -0.41 & -0.42 & 0.06 \\
\hline BMX Turbo RR & 0.30 & 0.29 & 0.17 & -0.40 & -0.43 & -0.03 & 0.15 & 0.40 & 0.38 & 0.76 \\
\hline
\end{tabular}

Note. ** Significant at $1 \%$ of probability; * Significant at $5 \%$ of probability. 
The highest concentration of nitrogen might be related to the increase of germinated and vigorous seeds, due to accelerated aging, allowing nitrogen availability, combined with the cultivar genetic potential and protein fraction present in the seeds (Delarmino-Ferraresi et al., 2014; Carvalho et al., 2015). These proteins act as enzymes in the initial stages of germination, where the reserve proteins are hydrolyzed, providing nutrition required by the embryo during germination process (Zimmer, 2012).

The correlation between viability, determined by the tetrazolium test, with nitrogen content was positive for the cultivarsBMX Ativa RR, BMX Impacto RR and NA 5909 RR, in the same way for vigor verified by the tetrazolium test. Nitrogen content was associated with germination for cultivarsBMX Apolo RR, BMX Ativa RR, BMX Impacto RR and BMX Potência RR. Accelerated aging correlated positively with nitrogen content in the cultivars BMX Apolo RR, BMX Impacto RR, BMX Magna RR and BMX Potência RR (Table 1).

The higher nitrogen concentration may be related to the increase of germinated seeds percentage and superior vigor determined through accelerated aging. This fact is justified by soybean to take advantage from nitrogen availability, genetic potential of the cultivar, protein content in the seeds and favorable conditions of the growing environments (Delarmino-Ferraresi et al., 2014; Ferrari et al., 2015; Souza et al., 2015). These proteins used during the germinative process act as enzymes, which in hydrolysis, nutritionally subsidize the embryo (Zimmer, 2012).

The correlation between viability determined by the tetrazolium test with nitrogen content was positive for the cultivars BMX Ativa RR, BMX Impacto RR and NA 5909 RR (Table 1). Regarding the correlation between weight of one thousand seeds and nitrogen content, the results were positive for the cultivars BMX Apolo RR, BMX Magna RR and BMX Turbo RR (Table 1). The weight of one thousand seeds is characterized as one of the main components of soybean yield, it expresses reduced effects for modifications imposed by growing environment, climatological and nutritional variables (Alvarez et al., 2007; Souza et al., 2015).

When analyzing the phosphorus content in soybean seeds, a positive correlation was observed with germination of the cultivars BMX Apolo RR, BMX Active RR, NA 5909 RR, BMX Potência RR and BMX Turbo RR. The accelerated aging test showed positive effects for cultivars BMX Força RR and BMX Turbo RR, regarding phosphorus content. This macronutrient is present in the seeds as a structural component of phospholipid membranes, phosphoproteins, phospholipids, component of nucleic acids and coenzymes, acting in the inorganic form being stored in vacuoles as orthophosphate, with function of producing chemical energy for physiological reactions, and their availability as energy source for the reactions during germination process (Zimmer, 2012; Silva et al., 2015).

Phosphorus content is related to the viability of the tetrazolium test, where positive results are observed for the cultivars BMX Apolo RR, BMX Ativa RR, BMX Impacto RR, BMX Potência RR and BMX Turbo RR. Similarly, the vigor obtained by this test shows positive effects for the cultivar BMX Impacto RR and BMX Potência RR. Trigo et al. (1997) demonstrated that high concentrations of phosphorus in the seeds provide greater energy availability for the seed metabolic activities, higher growth and initial development of seedlings in both aerial and root system, increase in nutrient absorption and productivity (Meira et al., 2015). In contrast, BatistellaFilho et al. (2013) verified that the increase in phosphorus concentration in the tissues, both leaf and seeds, did not affect the physiological quality of seeds produced, evaluated by germination and vigor tests.

The potassium content in soybean seeds positively correlated with percentage of germination for the cultivar BMX Ativa RR, with vigor by the tetrazolium test for the cultivar BMX Impacto RR (Table 1). Batistella Filho et al. (2013), when working with phosphate and potassium fertilization of soybean seeds revealed that seed's germinative capacity were not associated with potassium concentrations in the seeds. Tests reported by Turkiewicz (1976), involving wheat, rye and maize seeds, showed that the presence of P and K benefited seed vigor, although these elements were not associated with germination speed.

The calcium content in soybean seeds is associated with the percentage of germination, with positive results for the cultivars BMX Apolo RR, BMX Ativa RR, BMX Energia RR and NA 5909 RR. When analyzing the correlation of calcium content with accelerated aging, positive results were observed with the cultivars BMX Apolo RR, BMX Energy RR, BMX Magna RR, NA 5909 RR and BMX PotênciaRR (Table 1). The correlation of calcium content with viability by the tetrazolium test presented positive results for the cultivars BMX Apolo RR and BMX Potência RR. However, the vigor obtained by the tetrazolium test, when correlated with calcium content, did not present significant results for any of the cultivars analyzed. The content of magnesium in soybean seeds did not show significant responses to any of the measured characters.

Sulfur content (S) in the seeds showed positive association for germination, accelerated aging, viability and vigor of the seeds by tetrazolium test for cultivar the BMX Impacto RR (Table 1). In the same way, with mass of one 
thousand seeds for the cultivar BMX Turbo RR. The macronutrients nitrogen $(\mathrm{N})$, phosphorus $(\mathrm{P})$, potassium $(\mathrm{K})$, magnesium $(\mathrm{Mg})$ and sulfur $(\mathrm{S})$ revealed significant differences between seeds of the nine soybean cultivars analyzed, in contrast, potassium and calcium did not differ statistically between cultivars, (Table 2). Nitrogen content, for the cultivar BMX Ativa RR was higher than the other cultivars evaluated, being similar to the cultivars BMX Apolo RR, BMX Energia RR, BMX Força RR and BMX Potência RR (Table 2).

The cultivar with lower nitrogen content in the seeds was BMX Turbo RR, BMX Impacto RR, BMX Magna RR and NA 5909 RR, differing in 11.89 grams of nitrogen per kilogram of seeds among the cultivars BMX Ativa RR, with the highest accumulation, and BMX Turbo RR, with 19\% less in nitrogen accumulation. Since the protein content in different soybean cultivars varies from 30 to $45 \%$, and the nitrogen content is characterized as the base element of proteins evidences certain variation (Souza et al., 2009).

The highest nitrogen content was $63.76 \mathrm{~g} \mathrm{~kg}^{-1}$ for the cultivar BMX Ativa RR, with lower effects for the cultivar BMX Turbo RR. In relation to phosphorus content, the highest concentration of this nutrient was verified for the cultivar BMX Apolo RR, and inferiority for the BMX Impacto RR. For potassium content, superiority was conferred for the cultivar NA 5909 RR, with smaller effects for cultivar BMX Turbo RR. The higher calcium content was evidenced for cultivar NA 5909 RR, regarding magnesium and sulfur content, the cultivar BMX potênciaRR was superior for both macronutrients studied. The cultivars which presented the higher phosphorus content were BMX Apolo RR, BMX Turbo RR, BMX Força RR, BMX Potência RR, BMX Active RR and NA 5909 RR. According to Olibone and Rosolem (2010), the levels of phosphorus in soybean seeds vary according to the cultivar, growing environment, management techniques, and soil and climatic specific features. Batistella Filho et al. (2013) verified that phosphate fertilization increased the phosphorus fraction in both leaves and seeds of soybean, however, did not show effects to the seed physiological apparatus.

The potassium content in seeds of different cultivars analyzed did not reveal significant variations. Vieira et al. (1999) affirmed that, even if this element does not vary abruptly among cultivars, it has the purpose of balancing the tissues' electrolytes. The potassium content in seeds is essential for the initial phase of seedling growth, when the root system is poorly developed for an adequate supply of this nutrient (Malavolta, 2006; Epstein \& Bloom, 2006). Among several functions that this nutrient presents on plant metabolism, water absorption, enzymatic activation, meristematic tissue growth, protein and carbohydrate synthesis, assimilate translocation, and stomata opening and closing are prominent (Veiga et al., 2010). The highest magnesium content was verified for the cultivars BMX Potência RR, BMX Ativa RR, BMX Energia RR, BMX Magna RR and NA 5909 RR, in contrast, lower effects of this nutrient were expressed for the cultivar BMX Impacto RR compared to the other cultivars. The cultivars that presented higher sulfur contents were BMX Potência RR, BMX Impacto RR, BMX Ativa RR, BMX Turbo RR, BMX Apolo RR and BMX Força RR, lower emphasis of this nutrient was obtained for the cultivar NA 5909 RR.

\section{Conclusion}

The macronutrient contents of the seeds vary according to genetic characteristics of the cultivars, with higher oscillations of nitrogen, phosphorus, magnesium and sulfur contents present in soybean seeds.

Potassium and calcium are defined as the most stable nutrients for the cultivars and seed lots analyzed.

High concentrations of nitrogen, phosphorus and calcium are determinants for the physiological quality of soybean seeds.

\section{References}

Alvarez, R. C. F., Crusciol, C. A. C., Trivelin, P. C. O., Rodrigues, J. D., \& Alvarez, A. C. C. (2007). Influence of ethyl-trinexapac on $15 \mathrm{~N}$ accumulation and distribution and on highland rice yield. Revista Brasileira de Ciência do Solo, 31(6), 1487-1496. https://doi.org/10.1590/S0100-06832007000600025

Batistella Filho, F., Ferreira, M. E., Vieira, R. D., Da Cruz, M. C. P., Centurion, M. A. P. Da C., Sylvestre, T. De B., \& Ruiz, J. G. C. L. (2013). Phosphorus and potassium fertilization for yield and quality of soybean seeds. Brazilian Journal of Agricultural Research, 48(7), 783-790. Retrieved from http://www.scielo.br/ $\mathrm{pdf} / \mathrm{pab} / \mathrm{v} 48 \mathrm{n} 7 / 11 . \mathrm{pdf}$

Brazil. (2009). Ministério da Agricultura, Pecuária e Abastecimento. Regras para análise de sementes (p. 395). Ministério da Agricultura, Pecuária e Abastecimento. Secretaria de Defesa Agropecuária. Brasília, DF: Mapa/ACS.

Carvalho, I. R. (2017). Melhoramento e cultivo da soja (Vol. 1, p. 288). 
Carvalho, I. R., Souza, V. Q., Nardino, M., Follmann, D. N., Silva, A. D. B., Szareski, V. J., ... Olivoto, T. (2015). Associations Phenotypic between Physiological Traits of Soybean Contrasting Growth Habits. Global Science and Technology, 8, 30-40. https://doi.org/10.14688/1984-3801/gst.v8n3p30-40

Costa, N. P., França Neto, J. B., Krzyzanowski, F. C., \& Henning, A. A. (2007). Metodologia alternativa do teste de tetrazólio em sementes de soja. Circular Técnica, 39, 8. Retrieved from https://www.infoteca.cnptia. embrapa.br/bitstream/doc/467588/1/cirtec39sementes.pdf

Delarmelino-Ferraresi, L. M., Villela, F. A., \& Aumonde, T. Z. (2014). Physiological performance and chemical composition of soybean seeds. Revista Brasileira De Ciências Agrárias, 9(1), 14-18. https://doi.org/ 10.5039/agraria.v9i1a2864

Epstein, E., \& Bloom, A. J. (2006). Nutrição mineral de plantas: Princípios e perspectivas (p. 410). Londrina: Planta.

Ferrari, M., Nardino, M., Carvalho, I. R., Pelegrin, A. J., Belle, R., Szareski, V. J., ... Souza, V. Q. (2015). Water Absorbent: Alternative for Greater Tolerance to Drought. Global Science and Technology, 8, 21-29. https://doi.org/10.14688/1984-3801/gst.v8n3p21-29

Ferrari, M., Pelegrin, A. J., Souza, V. Q., Nardino, M., \& Carvalho, I. R. (2014). Efections on yield components of different treatment of seeds and leaf in the soybean. Enciclopédia Biosfera, 10, 532-538. Retrieved from https://rv.ifgoiano.edu.br/periodicos/index.php/gst/article/viewFile/741/479

Follmann, D. N., Souza, V. Q., Nardino, M., Carvalho, I. R., \& Demari, G. (2014). Different Associations for Additives in Pre-Seeding on Soybean and Yours Effects on Quality of Seed Produced. Enciclopédia Biosfera, 10, 1284-1292.

Malavolta, E. (2006). Manual de nutrição de plantas (p. 631). São Paulo: Agronômica Ceres.

Marcos Filho, J. (1999). Teste De Envelhecimento Acelerado. In F. Krzyzanowski, R. D. Vieira, J. B. França Neto (Eds.), Vigor De Sementes: Conceitos E Testes (pp. 1-24). Londrina: Abrates.

Marcos Filho, J. (2015). Fisiologia De Sementes De Plantas Cultivadas (2nd ed., p. 660). Londrina Abrates, Brazil.

Meira, D., Souza, V. Q., Carvalho, I. R., Nardino, M., Follmann, D. N., Meier, C., ... Pelegrin, A. J. (2015). Plastochron and morphological traits of soybean within determinate growth habit. Revista Cultivando o Saber, 8, 184-200.

Olibone, D., \& Rosolem, C. A. (2010). Phosphate fertilization and phosphorus forms in an Oxisol under no-till. ScientiaAgricola, 67, 465-471. https://doi.org/10.1590/S0103-90162010000400014

Panobianco, M., \& Marcos Filho, J. (2001). Accelerated aging and controlled deterioration of tomato seeds. Scientia Agrícola, 58, 525-531. https://doi.org/10.1590/S0103-90162001000300014

Peske, S. T., Villela, F. A., \& Meneghello, G. E. (2012). Sementes: Fundamentos Científicos e Tecnológicos (p. 573).

Schuch, L. O. B., Kolchinski, E. M., \& Finatto, J. A. (2009). Seed physiological quality and individual plants performance in soybean. Revista Brasileira de Sementes, 31(1), 144-149. https://doi.org/10.1590/S0101-31 222009000100016

Silva, A. D. B., Souza, V. Q., Follmann, D. N., Nardino, M., \& Carvalho, I. C. (2015). Physiological quality of soybean seeds in the second harvest. Enciclopédia Biosfera, 11, 1618-1623.

Souza, L. C. F., Zanon, G. D., Pedroso, F. F., \& Andrade, L. H. L. (2009). Protein and oil content in soybean grains as function of seed treatment and micronutrient application. Ciência e Agrotecnologia, 33(6), 1586-1593. https://doi.org/10.1590/S1413-70542009000600018

Souza, V. Q., Bellé, R., Ferrari, M., Pelegrin, A. J., Caron, B. O., Nardino, M., ... Carvalho, I. R. (2015). Yield components in fungicide and insecticide combinations and path analysis in soybean. Global Science and Technology, 8, 167-176. https://doi.org/10.14688/1984-3801/gst.v8n1p167-176

Souza, V. Q., Follmann, D. N., Nardino, M., Baretta, D., Carvalho, I. R., Caron, B. O., ... Demari, G. H. (2015). Production and vigor of soybean seeds produced with diferente seed tratment. Global Science and Technology, 8, 157-166. https://doi.org/10.14688/1984-3801/gst.v8n1p157-166

Szareski, V. J., Carvalho, I. R., Nardino, M., Demari, G. H., Bahry, C. A., Kehl, K., ... Aumonde, T. Z. (2016). Phenotype stability of soybean genotypes for characters related to the physiological quality of seeds 
produced under different environmental conditions. Australian Journal of Basic and Applied Sciences, 10(15), 279-289.

Szareski, V. J., Souza, V. Q., Carvalho, I. R., Nardino, M., Follmann, D. N., Demari, G. H., ... Olivoto, T. (2015). Growing environment and its effects on morphologic and bromatological traits of soybean. Revista Brasileira de Agropecuária Sustentável, 5(2), 79-88.

Trigo, L. F. N., Peske, S. T., Gastal, M. F. C., Vahl, L. C., \& Trigo, M. F. O. (1997). Effect of phosphorus content on soybean seed over grain yield of the resultant plant. Revista Brasileira de Sementes, 19(1), 111-115. https://doi.org/10.17801/0101-3122/rbs.v19n1p111-115

Turkiewicz, L. (1976). Efeito da calagem e adubação fosfatada sobre a germinação e o vigor de sementes de soja (Glycinemax (L.) Merrill) (p. 85). Piracicaba: ESALQ/USP.

Veiga, D. A., Von Pinho, E. V. R., Veiga, A., Pereira, P. H. A. R., Oliveira, K. C., \& Von Pinho, R. G. (2010). Influencia do potássio e da calagem na composição química qualidade fisiológica e na atividade enzimática de sementes de soja. Ciência e Agrotecnologia, 34(4), 953-960. https://doi.org/10.1590/S1413-70542010 000400022

Vieira, C. R., Cabral, L. C., \& De Paula, A. C. O. (1999). Centesimal composition and content of amino acids, fat acids, and minerals of six soybean cultivars destined to human feed. Brazilian Journal of Agricultural Research, 34(7), 1277-1283.

Zimmer, P. D. (2012). Fundamentos da qualidade de sementes. In S. T. Peske, F. A. Villela, \& G. E. Meneghello (Eds.), Sementes: Fundamentoscientíficos e tecnológicos (pp. 16-106). Pelotas: Universitária/UFPel.

\section{Copyrights}

Copyright for this article is retained by the author(s), with first publication rights granted to the journal.

This is an open-access article distributed under the terms and conditions of the Creative Commons Attribution license (http://creativecommons.org/licenses/by/4.0/). 